\title{
Analisis Permintaan Karet Alam Indonesia di Pasar Internasional
}

D $01: 10.18196 /$ agr.1217

\begin{abstract}
The development of the natural rubber market in three years was relatively favorable for producers, which was indicated by the relatively high price level. This was due to increasing demand. Of course this will be a good opportunity for Indonesia to export processed rubber and rubber industry in Indonesia to other countries. The purpose of this study was to determine the factors that can affect demand for Indonesia's natural rubber exports in each country's export destinations. The data used was secondary data years 1980-2013 time series derived from IRSG, BPS, FAO, Gapkindo, UN Comtrade, BI, and the World Bank. Methods of analysis using dynamic demand model "Stock Adjustment Principle", Nerlove (1983) and the model
\end{abstract}

of Ordinary Least Square (OLS), Auto Correlation Models and Two Stage Least Square (2SLS) with modifications to several independent variables. The results showed that Indonesia's natural rubber demand in the market of the United States, China, Japan, Singapore, and South Korea is positively influenced by the volume of exports last year, the population of a country, and per capita income of a country. As well as negatively affected by the exchange rate of a country's currency against the US dollar and the implementation of the export quota policy.

Keywords: demand for exports, Indonesia natural rubber, importing countries.

\section{INTISARI}

Pengembangan pasar karet alam dalam tiga tahun terakhir relatif menguntungkan bagi produsen, diindikasikan oleh tingkat harga yang relatif tinggi. Ini terjadi karena peningkatan permintaan. Tentu saja ini menjadi peluang yang baik bagi Indonesia untuk mengekspor karet olahan dan karet industri Indonesia ke berbagai Negara. Tujuan dari penelitian ini adalah menentukan faktor yang berpengaruh terhadap permintaan karet alam Indonesia pada masing-masing negara tujuan ekspor. Data yang digunakan adalah data time series, data tahunan selama periode 1980-2013 yang diperoleh dari IRSG, BPS, FAO, Gapkindo, UN Comtrade, BI, dan Bank Dunia. Metode analisis yang digunakan adalah model permintaan dinamis "Stock Adjustment Principle", Nerlove (1983) dan model OLS, serta model auto korelasi dan model 2SLS dengan modifikasi beberapa variabel independen. Hasil penelitian menunjukkan bahwa permintaan karet alam Indonesia di AS, China, Jepang, Singapura, dan Korea Selatan dipengaruhi secara positif oleh volume ekspor tahun sebelumnya, jumlah penduduk, dan pendapatan per kapita. Dan secara negatif dipengaruhi oleh nilai tukar mata uang negara tersebut terhadap dollar AS, dan implementasi kebijakan kuota ekspor. Kata kunci: permintaan ekspor, karet alam Indonesia, negara importir. 


\section{PENDAHULUAN}

Perkebunan merupakan sub sektor pertanian yang mempunyai peran penting dalam perekonomian Indonesia. Menurut Payaman (1983) perkebunan adalah komoditi di luar minyak dan gas alam yang mempunyai potensi dan prospek cukup baik di pasaran dunia. Karet merupakan komoditi utama sektor perkebunan di Indonesia selain kelapa sawit dan kelapa, yang perlu mendapat perhatian dari pemerintah.

Karet alam merupakan salah satu komoditi perkebunan yang sangat penting peranannya dalam perekonomin Indonesia. Selain sebagai sumber pendapatan dan kesejahteraan masyarakat serta sebagai pendorong pertumbuhan ekonomi sentra-sentra baru di wilayah sekitar perkebunan karet, komoditi ini juga memberikan kontribusi yang signifikan sebagai sumber devisa negara, mengingat $84 \%$ produksi karet alam Indonesia diekspor dalam bentuk karet mentah sementara konsumsi karet domestik baru mencapai 16\%. Karet bersama-sama dengan kelapa sawit merupakan dua komoditas utama penghasil devisa terbesar dari subsektor perkebunan, dalam kurun waktu 5 tahun terakhir karet menyumbang devisa $25 \%-40 \%$ terhadap total ekspor produk perkebunan.

Meningkatnya permintaan dunia terhadap karet menjadi peluang bagi Indonesia untuk menempatkan diri sebagai produsen utama karet dunia. Bukan saja intensifikasi yang dapat dilakukan oleh Indonesia, tetapi juga ekstensifikasi, yang tidak mungkin dilakukan Thailand maupun Malaysia karena keterbatasan lahan. Indonesia masih dapat mengembangkan perkebunan karet lebih luas lagi karena masih banyaknya lahan kosong seperti hutan yang gundul, semak belukar, dan padang alang-alang yang seharusnya cepat ditanam pohon karet yang memiliki kemampuan tumbuh dengan baik di lahan apa saja. Dengan demikian keuntungan yang diperoleh tidak hanya dari meningkatnya produksi karet alam Indonesia, tetapi diharapkan mampu memperbaiki kondisi lingkungan melalui rehabilitasi lahan gundul dan lahan marginal lainnya.

Berdasarkan latar belakang dan rumusan masalah di atas, maka tujuan penelitian ini adalah untuk: mengetahui faktor-faktor apa saja yang dapat mempengaruhi permintaan ekspor karet alam Indonesia pada masing-masing negara tujuan ekspor (negara importir).

\section{METODE PENELITIAN}

Data dalam penelitian ini dikumpulkan melalui pencatatan dari berbagai sumber penerbitan maupun dari kantor atau instansi yang berkaitan dengan karet. Data yang digunakan dalam penelitian ini adalah data sekunder time series tahun 1980 - 2013 yang berasal dari instansi yang berhubungan dengan penelitian, antara lain: IRSG (International Rubber Statistic Group), ANRPC (Asosiation Natural Rubber Producing Countries), FAO (Food and Agriculture Organization), Gapkindo (Gabungan Pengusaha Karet Indonesia), BPS (Biro Pusat Statistik), kementerian Pertanian, Dinas Perkebunan, Kementerian Industri dan perdagangan, Bank Indonesia dan Bank Dunia, UN Comtrade.

Metode Analisis Data

Volume ekspor jangka pendek dan jangka panjang dianalisis dengan menggunakan model permintaan dinamis "Stock Adjusment Principle" Nerlove dan model analisis Ordinary Least Square (OLS), Auto Correlation Models dan Two Stage Least Square (2SLS) dengan modifikasi beberapa variabel independen. Model persamaan permintaan dipakai dengan asumsi harga yang terjadi merupakan interaksi permintaan dan penawaran. Persamaan struktural dalam penelitian ini adalah sebagai berikut.

Persamaan Permintaan

$$
\begin{gathered}
\ln Q_{\mathrm{dt}}=\ln \alpha+\alpha_{1} \ln \mathrm{P}_{\mathrm{t}}+\alpha_{2} \ln \mathrm{I}_{\mathrm{t}}+\alpha_{3} \ln \mathrm{S}_{\mathrm{t}}+\alpha_{4} \ln E R_{\mathrm{t}}+\alpha_{5} \ln \mathrm{PA}_{\mathrm{t}}+\alpha_{6} \ln \mathrm{P}_{\mathrm{d}} \\
+\alpha_{7} \operatorname{lnRCA_{\mathrm {t}}}+\alpha_{8} \ln \mathrm{nOp}_{\mathrm{t}}+\alpha_{9} \ln \mathrm{Q}_{\mathrm{dt}-1}+\alpha_{10} \mathrm{D}_{\mathrm{t}}+\mu_{\mathrm{t}}
\end{gathered}
$$

dimana:

$\mathrm{Q}_{\mathrm{dt}}=\quad$ volume ekspor karet alam Indonesia ke negara importir (ribu ton)

$\mathrm{Pt}=\quad$ harga riil karet alam Indonesia di pasar internasional (Amerika Serikat), (US\$)

It $=\quad$ pendapatan per kapita negara importir (US\$)

St $=$ harga riil karet alam dalam negeri/dmestik (US\$)

$E R t=$ nilai tukar (Exchange rate) rupiah terhadap US\$

$D t=$ kebijakan kuota ekspor (dummy variable, ada kebijakan kuota $=1$ dan tidak ada kebijakan kuota $=0$ )

$\mathrm{Pd}=\quad$ harga riil karet alam domestic/dalam negeri $(\mathrm{Rp} / \mathrm{kg})$

PAt $=$ harga riil karet sintetis negara importir (US\$) 
TABEL I. FAKTOR-FAKTOR YANG MEMPENGARUHI PERMINTAAN KARET ALAM INDONESIA

\begin{tabular}{llll}
\hline No & Nama Variabel & Koef. regresi & T-hitung \\
\hline 1 & Volume ekspor tahun lalu ke Amerika Serikat (Qdt_l) & $0,2250^{* * *}$ & 8,080 \\
2 & Harga riil karet alam di pasar internasional (Pt) & $-0,3440^{* * *}$ & $-3,206$ \\
3 & Harga riil karet alam dalam negeri (Pd) & $-0,0100^{\text {NS }}$ & $-0,097$ \\
4 & Harga riil karet sintetis (PAt) & $0,2014^{*}$ & 1,792 \\
5 & Pendapatan per kapita Amerika Serikat (It) & $1,4369^{* * *}$ & 3,059 \\
6 & Nilai tukar rupiah terhadap US\$ (ERt) & $-0,3418^{* * *}$ & $-2,691$ \\
7 & Populasi penduduk Amerika Serikat (Popt) & $4,0033^{*}$ & 1,806 \\
8 & Kebijakan kuota ekspor (Dummy) & $-0,1353^{* *}$ & $-2,445$ \\
9 & Constant & $14,9850^{* * *}$ & 8,080 \\
\hline & $R^{2}$ & 0,9282 & \\
& $F_{\text {hit }}$ & & $53,157^{* * *}$ \\
& Durbin Watson Test (DW) & & 1,9774 \\
\hline
\end{tabular}

Keterangan: ${ }^{* * *}$ ) signifikan pada á $=1 \%$; ${ }^{* *}$ ) signifikan pada á $=5 \%$; ${ }^{*}$ ) siginifikan pada á $=10 \%$; Ns $=$ tidak signifikan

Pop $_{\mathrm{t}}=\quad$ populasi penduduk negara importir (jiwa)

$\mathrm{Q}_{\mathrm{dt}-1}=\quad$ volume ekspor karet alam Indonesia ke negara importir tahun lalu (ribu ton)

$\dot{a}_{i}(i=1,2, \ldots, 10)=$ koefisien regresi

$\mu_{\mathrm{t}} \quad=$ an error term

\section{HASIL DAN PEMBAHASAN}

\section{NEGARA AMERIKA SERIKAT}

Hasil analisis faktor-faktor yang mempengaruhi volume ekspor karet alam Indonesia ke Negara Amerika Serikat seperti ditunjukkan pada Tabel 1 .

Uji secara keseluruhan dari hasil analisis permintaan ekspor karet alam Indonesia ke Negara Amerika Serikat diperoleh nilai koefisien determinasi $\left(R^{2}\right)$ sebesar 0,9282. Hal ini berarti sekitar $92,82 \%$ variasi volume ekspor karet alam Indonesia ke Negara Amerika Serikat dapat dijelaskan oleh volume ekspor karet alam Indonesia ke negara importir tahun lalu, harga riil karet alam Indonesia di pasar internasional, harga riil karet alam dalam negeri/domestik, harga riil karet sintetis negara importir, pendapatan per kapita negara importir, nilai tukar (exchange rate) rupiah terhadap US\$, populasi penduduk negara importir, dan kebijakan kuota ekspor yang ada dalam model, sementara sisanya $(7,18 \%)$ ditentukan oleh variabel bebas lain di luar model analisis yang digunakan.

Untuk melihat pengaruh secara keseluruhan variabel bebas (volume ekspor karet alam Indonesia ke negara importir tahun lalu, harga riil karet alam Indonesia di pasar internasional, harga riil karet alam dalam negeri/ dmestik, harga riil karet sintetis negara importir, pendapatan per kapita negara importir, nilai tukar (exchange rate) rupiah terhadap US\$, populasi penduduk negara importir, dan kebijakan kuota ekspor) secara bersama-sama terhadap volume ekspor karet alam Indonesia ke Negara Amerika Serikat digunakan uji Ftest. Bersasrkan hasil analisis pada Tabel 1 diperoleh nilai F-hitung sebesar 53,157 dan nilai ini jauh lebih besar dari nilai F-tabel pada tingkat kesalahan 1\% (á = $1 \%$ ). Hal ini menunjukkan bahwa variabel bebas dalam model secara bersama-sama berpengaruh nyata terhadap volume ekspor karet alam Indonesia ke Negara Amerika Serikat pada tingkat kepercayaan 99\%.

Untuk melihat pengaruh masing-masing variabel bebas (volume ekspor karet alam Indonesia ke negara importir tahun lalu, harga riil karet alam Indonesia di pasar internasional, harga riil karet alam dalam negeri/ dmestik, harga riil karet sintetis negara importir, pendapatan per kapita negara importir, nilai tukar (exchange rate) rupiah terhadap US\$, populasi penduduk negara importir, dan kebijakan kuota ekspor) terhadap volume ekspor karet alam Indonesia ke Negara Amerika Serikat digunakan uji t-test. Berdasarkan hasil analisis uji t-test pada Tabel 1, variabel harga karet alam Indonesia di pasar internasional, volume ekspor karet alam Indonesia ke Negara Amerika Serikat satu tahun sebelumnya, harga riil karet sintetis di pasar internasional, nilai tukar, 
jumlah penduduk Amerika Serikat, pendapatan per kapita Amerika Serikat secara statistik berpengaruh atau signifikan terhadap volume ekspor karet alam Indonesia ke Negara Amerika Serikat.

Pada Tabel 1 volume ekspor karet alam Indonesia ke Negara Amerika Serikat satu tahun sebelumnya secara statistik menunjukkan pengaruh yang signifikan dan positif terhadap volume ekspor karet alam Indonesia ke Negara Amerika Serikat pada tingkat kepercayaan 99\%. Hal ini berarti bahwa apabila volume ekspor karet alam Indonesia ke Negara Amerika Serikat satu tahun sebelumnya meningkat $1 \%$ dengan asumsi faktor lain dalam keadaan cateris paribus (tetap), maka volume ekspor karet alam Indonesia ke Negara Amerika Serikat mengalami peningkatan sebesar 0,2250\%. Oleh karena itu, volume ekspor karet alam Indonesia ke Negara Amerika Serikat satu tahun sebelumnya terdapat kecenderungan volume ekspor karet alam ke Negara Amerika Serikat tahun berikut mengalami peningkatan.

Harga riil karet alam di pasar internasional secara statistik berpengaruh nyata terhadap volume ekspor karet alam Indonesia ke Negara Amerika Serikat pada tingkat kepercayaan 99\%. Besarnya nilai koefisien regresi dari variabel harga riil karet alam di pasar internasional adalah sebesar -0,3440. Hal ini menunjukkan bahwa apabila harga riil karet alam di pasar internasional meningkat $1 \%$ dengan asumsi faktor lain dalam keadaan tetap, maka volume ekspor karet alam Indonesia ke Negara Amerika Serikat mengalami penurunan sebesar nilai koefisien regresi dari variabel harga riil karet alam di pasar internasional $(0,3440)$.

Selanjutnya, harga riil karet sintetis di pasar internasional secara statistik juga berpengaruh nyata dan positif terhadap volume ekspor karet alam Indonesia ke Negara Amerika Serikat pada tingkat kepercayaan 90\%. Besarnya nilai koefisien regresi dari variabel harga riil karet sintetis di pasar internasional adalah sebesar 0,2014 . Hal ini menunjukkan bahwa, apabila harga riil karet sintetis di pasar internasional meningkat $1 \%$ dengan asumsi faktor lain dalam keadaan tetap, maka volume ekspor karet alam Indonesia ke Negara Amerika Serikat akan mengalami peningkatan sebesar nilai koefisien regresi dari variabel harga riil karet sintetis di pasar internasional $(0,2014)$. Hal ini menunjukkan bahwa karet sintetis merupakan barang subtitusi dari karet alam.

Selanjutnya, nilai tukar (exchange rate) US\$ terhadap rupiah secara statistik juga berpengaruh nyata dan negatif terhadap volume ekspor karet alam Indonesia ke Negara
Amerika Serikat pada tingkat kepercayaan 99\%. Besarnya nilai koefisien regresi dari variabel nilai tukar (exchange rate) US\$ terhadap rupiah adalah sebesar -0,3418. Hal ini menunjukkan bahwa, apabila nilai tukar (exchange rate) rupiah terhadap US\$ meningkat 1\% dengan asumsi faktor lain dalam keadaan tetap, maka volume ekspor karet alam Indonesia ke Negara Amerika Serikat akan mengalami penurunan sebesar 0,3418\%.

Jumlah penduduk Negara Amerika Serikat secara statistik berpengaruh nyata terhadap volume ekspor karet alam Indonesia ke Negara Amerika Serikat pada tingkat kepercayaan 90\%. Besarnya nilai koefisien regresi dari variabel jumlah penduduk Negara Amerika Serikat adalah sebesar 4,0033. Hal ini menunjukkan bahwa apabila jumlah penduduk Negara Amerika Serikat meningkat 1\% dengan asumsi faktor lain dalam keadaan tetap, maka volume ekspor karet alam Indonesia ke Negara Amerika Serikat mengalami peningkatan sebesar nilai koefisien regresi dari variabel jumlah penduduk Negara Amerika Serikat yakni sebesar 4,0033\%.

Variabel pendapatan per kapita Negara Amerika Serikat juga secara statistik berpengaruh nyata dan positif terhadap volume ekspor karet alam Indonesia ke Negara Amerika Serikat pada tingkat kepercayaan 99\%. Besarnya nilai koefisien regresi dari variabel pendapatan per kapita Negara Amerika Serikat adalah sebesar 1,4369. Hal ini menunjukkan bahwa apabila pendapatan per kapita Negara Amerika Serikat meningkat 1\% dengan asumsi faktor lain dalam keadaan tetap, maka volume ekspor karet alam Indonesia ke Negara Amerika Serikat mengalami peningkatan sebesar nilai koefisien regresi dari variabel pendapatan per kapita Negara Amerika Serikat yakni sebesar 1,4369.

Kebijakan kuota ekspor secara statistik menunjukkan pengaruh yang signifikan terhadap volume ekspor karet alam Indonesia ke Negara Amerika Serikat. Hal ini menunjukkan bahwa terdapat perbedaan yang signifikan terhadap volume ekspor karet alam Indonesia dengan dikeluarkan kebijakan pembatasan kuota ekspor yakni adanya kebijakan kuota ekspor tersebut dapat menghambat atau menurunkan volume ekspor karet alam ke Negara Amerika Serikat. Besarnya nilai penurunan volume ekspor karet alam ke Negara Amerika Serikat dengan adanya kebijakan pembatasan kuota ekspor adalah sebesar 0,1353\%.

Variabel bebas lain yang masuk dalam model analisis yaitu harga riil karet alam dalam negeri secara statistik tidak menunjukkan pengaruh yang nyata (non signifikan) 
terhadap volume ekspor karet alam Indonesia ke Negara Amerika Serikat. Hal ini menunjukkan bahwa terjadinya perubahan pada nilai dari variabel harga riil karet alam dalam negeri dan nilai tukar rupiah terhadap US\$ secara statistik tidak berpengaruh terhadap volume ekspor karet alam Indonesia ke Negara Amerika Serikat.

\section{NEGARA CHINA}

Hasil analisis faktor-faktor yang mempengaruhi Volume ekspor karet alam Indonesia ke Negara China seperti ditunjukkan pada Tabel 2.

\section{TABEI 2. FAKTOR-FAKTOR YANG MEMPENGARUHI PERMINTAAN KARET ALAM INDONESIA KE NEGARA CHINA.}

\begin{tabular}{|c|c|c|c|}
\hline No & Nama Variabel & Koef. regresi & T-hitung \\
\hline 1 & $\begin{array}{l}\text { Volume ekspor tahun lalu ke } \\
\text { China (Qdt_1) }\end{array}$ & $0,5345^{* * *}$ & 4,105 \\
\hline 2 & $\begin{array}{l}\text { Harga riil karet alam di } \\
\text { pasar internasional (Pt) }\end{array}$ & $-0,7663^{\text {NS }}$ & $-1,116$ \\
\hline 3 & $\begin{array}{l}\text { Harga riil karet alam dalam } \\
\text { negeri (Pd) }\end{array}$ & $-1,1158 *$ & $-1,687$ \\
\hline 4 & Harga riil karet sintetis (PAt) & $0,5092^{*}$ & 1,687 \\
\hline 5 & $\begin{array}{l}\text { Pendapatan per kapita } \\
\text { Negara China (It) }\end{array}$ & $0,3227^{* * *}$ & 3,601 \\
\hline 6 & $\begin{array}{l}\text { Nilai tukar Yuan terhadap } \\
\text { US\$ (ERt) }\end{array}$ & $-0,9389^{* * *}$ & $-2,879$ \\
\hline 7 & $\begin{array}{l}\text { Jumlah penduduk Negara } \\
\text { China (Popt) }\end{array}$ & $1,4477^{* * *}$ & 4,187 \\
\hline 8 & $\begin{array}{l}\text { Kebijakan kuota ekspor } \\
\text { (Dummy) }\end{array}$ & $-1,5148^{* * *}$ & $-4,241$ \\
\hline 9 & $\begin{array}{l}\text { Constant } \\
R^{2}\end{array}$ & $\begin{array}{l}-118,4061^{*} \\
0,8532\end{array}$ & 1,789 \\
\hline & $\begin{array}{l}\mathrm{F}_{\text {hit }} \\
\text { Durbin Watson Test (DW) }\end{array}$ & & $\begin{array}{l}48,143^{* * *} \\
1,9207\end{array}$ \\
\hline
\end{tabular}

Keterangan: ${ }^{* *}$ ) signifikan pada á $=1 \% ;{ }^{* *}$ ) signifikan pada á $=5 \%$; ) siginifikan pada á $=10 \%$; ${ }^{\text {Ns }}=$ tidak signifikan

Uji secara keseluruhan dari hasil analisis permintaan ekspor karet alam Indonesia ke Negara China diperoleh nilai koefisien determinasi $\left(R^{2}\right)$ sebesar 0,8532 . Hal ini berarti sekitar $85,32 \%$ variasi volume ekspor karet alam Indonesia ke Negara China dapat dijelaskan oleh volume ekspor karet alam Indonesia ke negara importir tahun lalu, harga riil karet alam Indonesia di pasar internasional, harga riil karet alam dalam negeri/ dmestik, harga riil karet sintetis negara importir, pendapatan per kapita negara importir, nilai tukar (exchange rate) Yuan terhadap US\$, populasi penduduk negara importir, dan kebijakan kuota ekspor yang ada dalam model, sementara sisanya $(14,68 \%)$ variasi volume ekspor karet alam Indonesia ke Negara China ditentukan oleh variabel bebas lain di luar model analisis yang digunakan.

Untuk melihat pengaruh secara keseluruhan variabel bebas (volume ekspor karet alam Indonesia ke negara importir tahun lalu, harga riil karet alam Indonesia di pasar internasional, harga riil karet alam dalam negeri/ dmestik, harga riil karet sintetis negara importir, pendapatan per kapita negara importir, nilai tukar (exchange rate) Yuan terhadap US\$, populasi penduduk negara importir, dan kebijakan kuota ekspor) secara bersama-sama terhadap volume ekspor karet alam Indonesia ke Negara China digunakan uji F-test. Bersastkan hasil analisis pada Tabel 2 diperoleh nilai Fhitung sebesar 48,143 dan nilai ini jauh lebih besar dari nilai F-tabel pada tingkat kesalahan 1\% (á = 1\%). Hal ini menunjukkan bahwa variabel bebas dalam model secara bersama-sama berpengaruh nyata terhadap volume ekspor karet alam Indonesia ke Negara China pada tingkat kepercayaan $99 \%$.

Untuk melihat pengaruh masing-masing variabel bebas (volume ekspor karet alam Indonesia ke negara importir tahun lalu, harga riil karet alam Indonesia di pasar internasional, harga riil karet alam dalam negeri/ dmestik, harga riil karet sintetis negara importir, pendapatan per kapita negara importir, nilai tukar (exchange rate) Yuan terhadap US\$, populasi penduduk negara importir, dan kebijakan kuota ekspor) terhadap volume ekspor karet alam Indonesia ke Negara China digunakan uji t-test. Berdasarkan hasil analisis uji t-test pada Tabel 2 menunjukkan bahwa variabel volume ekspor karet alam Indonesia ke Negara China satu tahun sebelumnya, harga karet alam dalam negeri, harga riil karet sintetis di pasar internasional, nilai tukar (exchange rate) Yuan terhadap US\$, jumlah penduduk China, dan pendapatan per kapita China secara statistik berpengaruh atau signifikan terhadap volume ekspor karet alam Indonesia ke Negara China.

Pada Tabel 2 volume ekspor karet alam Indonesia ke Negara China satu tahun sebelumnya secara statistik menunjukkan pengaruh yang signifikan dan positif terhadap volume ekspor karet alam Indonesia ke Negara China pada tingkat kepercayaan 99\%. Hal ini berarti bahwa apabila volume ekspor karet alam Indonesia ke 
Negara China satu tahun sebelumnya meningkat 1\% dengan asumsi faktor lain dalam keadaan cateris paribus (tetap), maka volume ekspor karet alam Indonesia ke Negara China mengalami peningkatan sebesar 0,5345\%. Oleh karena itu, volume ekspor karet alam Indonesia ke Negara China satu tahun sebelumnya terdapat kecenderungan volume ekspor karet alam ke Negara China tahun berikut mengalami peningkatan.

Harga riil karet alam di dalam negeri/domestik secara statistik berpengaruh nyata dan negative terhadap volume ekspor karet alam Indonesia ke Negara China pada tingkat kepercayaan 99\%. Besarnya nilai koefisien regresi dari variabel harga riil karet alam di dalam negeri/ domestik adalah sebesar -1,1158. Hal ini menunjukkan bahwa apabila harga riil karet alam di dalam negeri/ domestik meningkat 1\% dengan asumsi faktor lain dalam keadaan tetap, maka volume ekspor karet alam Indonesia ke Negara China mengalami penurunan sebesar nilai koefisien regresi dari variabel harga riil karet alam di dalam negeri/domestik yakni sebesar 1,1158\%.

Selanjutnya, harga riil karet sintetis di pasar internasional secara statistik juga berpengaruh nyata dan positif terhadap volume ekspor karet alam Indonesia ke Negara China pada tingkat kepercayaan 99\%. Besarnya nilai koefisien regresi dari variabel harga riil karet sintetis di pasar internasional adalah sebesar 0,5092. Hal ini menunjukkan bahwa, apabila harga riil karet sintetis di pasar internasional meningkat 1\% dengan asumsi faktor lain dalam keadaan tetap, maka volume ekspor karet alam Indonesia ke Negara China akan mengalami peningkatan sebesar nilai koefisien regresi dari variabel harga riil karet sintetis di pasar internasional (0,5092\%). Hal ini menunjukkan bahwa karet sintetis merupakan barang subtitusi dari karet alam.

Selanjutnya, nilai tukar (exchange rate) Yuan terhadap US\$ secara statistik juga berpengaruh nyata dan negatif terhadap volume ekspor karet alam Indonesia ke Negara China pada tingkat kepercayaan 99\%. Besarnya nilai koefisien regresi dari variabel nilai tukar (exchange rate) Yuan terhadap US\$ adalah sebesar -0,9389. Hal ini menunjukkan bahwa, apabila nilai tukar (exchange rate) Yuan terhadap US\$ meningkat 1\% dengan asumsi faktor lain dalam keadaan tetap, maka volume ekspor karet alam Indonesia ke Negara China akan mengalami penurunan sebesar nilai koefisien regresi dari variabel nilai tukar (exchange rate) Yuan terhadap US\$ yakni sebesar 0,9389\%.

Jumlah penduduk Negara China secara statistik berpengaruh nyata terhadap volume ekspor karet alam Indonesia ke Negara China pada tingkat kepercayaan 99\%. Besarnya nilai koefisien regresi dari variabel jumlah penduduk Negara China adalah sebesar 1,4477. Hal ini menunjukkan bahwa apabila jumlah penduduk Negara China meningkat 1\% dengan asumsi faktor lain dalam keadaan tetap, maka volume ekspor karet alam Indonesia ke Negara China mengalami peningkatan sebesar nilai koefisien regresi dari variabel jumlah penduduk Negara China yakni sebesar 1,4477\%.

Variabel pendapatan per kapita Negara China juga secara statistik berpengaruh nyata dan positif terhadap volume ekspor karet alam Indonesia ke Negara China pada tingkat kepercayaan 99\%. Besarnya nilai koefisien regresi dari variabel pendapatan per kapita Negara China adalah sebesar 0,3227. Hal ini menunjukkan bahwa apabila pendapatan per kapita Negara China meningkat 1\% dengan asumsi faktor lain dalam keadaan tetap, maka volume ekspor karet alam Indonesia ke Negara China mengalami peningkatan sebesar nilai koefisien regresi dari variabel pendapatan per kapita Negara China yakni sebesar 0,3227\%.

Kebijakan kuota ekspor secara statistik menunjukkan pengaruh yang signifikan terhadap volume ekspor karet alam Indonesia ke Negara China. Hal ini menunjukkan bahwa terdapat perbedaan yang signifikan terhadap volume ekspor karet alam Indonesia dengan dikeluarkan kebijakan pembatasan kuota ekspor yakni adanya kebijakan kuota ekspor tersebut dapat menghambat atau menurunkan volume ekspor karet alam ke Negara China. Besarnya nilai penurunan volume ekspor karet alam ke Negara China dengan adanya kebijakan pembatasan kuota ekspor adalah sebesar 1,5148\%.

Variabel bebas lain yang masuk dalam model analisis yaitu harga riil karet alam dalam di pasar internasional secara statistik tidak menunjukkan pengaruh yang nyata (non signifikan) terhadap volume ekspor karet alam Indonesia ke Negara China. Hal ini menunjukkan bahwa terjadinya perubahan pada nilai dari variabel harga riil karet alam dalam di pasar internasional secara statistik tidak berpengaruh terhadap volume ekspor karet alam Indonesia ke Negara China.

\section{NEGARA JEPANG}

Hasil analisis faktor-faktor yang mempengaruhi Volume ekspor karet alam Indonesia ke Negara Jepang seperti ditunjukkan pada Tabel 3. 
TABEI 3. FAKTOR-FAKTOR YANG MEMPENGARUHI PERMINTAAN KARET ALAM INDONESIA KE NEGARA JEPANG

\begin{tabular}{|c|c|c|c|}
\hline No & Nama Variabel & Koef. regresi & T-hitung \\
\hline 1 & $\begin{array}{l}\text { Volume ekspor tahun lalu ke } \\
\text { Jepang (Qdt_l) }\end{array}$ & $0,5902^{* *}$ & 2,436 \\
\hline 2 & $\begin{array}{l}\text { Harga riil karet alam di pasar } \\
\text { internasional (Pt) }\end{array}$ & $-0,5387^{*}$ & $-1,820$ \\
\hline 3 & $\begin{array}{l}\text { Harga riil karet alam dalam } \\
\text { negeri }(\mathrm{Pd})\end{array}$ & $-0,2783^{*}$ & $-2,005$ \\
\hline 4 & Harga riil karet sintetis (PAt) & $0,2800^{*}$ & 1,849 \\
\hline 5 & $\begin{array}{l}\text { Pendapatan per kapita Jepang } \\
(\mathrm{II})\end{array}$ & $0,8221^{* * *}$ & 4,891 \\
\hline 6 & $\begin{array}{l}\text { Nilai tukar Yen Jepang terhadap } \\
\text { US\$ (ERt) }\end{array}$ & $-0,4489 * * *$ & $-4,284$ \\
\hline 7 & Populasi penduduk Jepang (Popt) & $3,6659^{*}$ & 1,966 \\
\hline 8 & Kebijakan kuota ekspor (Dummy) & $-0,4145^{* * *}$ & $-3,378$ \\
\hline 9 & $\begin{array}{l}\text { Constant } \\
R^{2}\end{array}$ & $\begin{array}{l}13,3796^{* * *} \\
0,9757\end{array}$ & 4,226 \\
\hline & $\begin{array}{l}\mathrm{F}_{\text {hit }} \\
\text { Durbin Watson Test (DW) }\end{array}$ & & $\begin{array}{l}125,021^{* * *} \\
1,9191\end{array}$ \\
\hline
\end{tabular}

Uji secara keseluruhan dari hasil analisis permintaan ekspor karet alam Indonesia ke Negara Jepang diperoleh nilai koefisien determinasi $\left(\mathrm{R}^{2}\right)$ sebesar 0,9756 . Hal ini berarti sekitar $97,56 \%$ variasi volume ekspor karet alam Indonesia ke Negara Jepang dapat dijelaskan oleh volume ekspor karet alam Indonesia ke negara importir tahun lalu, harga riil karet alam Indonesia di pasar internasional, harga riil karet alam dalam negeri/ dmestik, harga riil karet sintetis negara importir, pendapatan per kapita negara importir, nilai tukar (exchange rate) Yen Jepang terhadap US\$, populasi penduduk negara importir, dan kebijakan kuota ekspor yang ada dalam model, sementara sisanya $(2,44 \%)$ variasi volume ekspor karet alam Indonesia ke Negara Jepang ditentukan oleh variabel bebas lain di luar model analisis yang digunakan.

Untuk melihat pengaruh secara keseluruhan variabel bebas (volume ekspor karet alam Indonesia ke negara importir tahun lalu, harga riil karet alam Indonesia di pasar internasional, harga riil karet alam dalam negeri/ dmestik, harga riil karet sintetis negara importir, pendapatan per kapita negara importir, nilai tukar (exchange rate) Yen Jepang terhadap US\$, populasi penduduk negara importir, dan kebijakan kuota ekspor) secara bersama-sama terhadap volume ekspor karet alam Indonesia ke Negara Jepang digunakan uji F-test. Bersasrkan hasil analisis pada Tabel 3 diperoleh nilai Fhitung sebesar 125,021 dan nilai ini jauh lebih besar dari nilai F-tabel pada tingkat kesalahan 1\% (á = 1\%). Hal ini menunjukkan bahwa variabel bebas dalam model secara bersama-sama berpengaruh nyata terhadap volume ekspor karet alam Indonesia ke Negara Jepang pada tingkat kepercayaan $99 \%$.

Untuk melihat pengaruh masing-masing variabel bebas (volume ekspor karet alam Indonesia ke negara importir tahun lalu, harga riil karet alam Indonesia di pasar internasional, harga riil karet alam dalam negeri/ dmestik, harga riil karet sintetis negara importir, pendapatan per kapita negara importir, nilai tukar (exchange rate) Yen Jepang terhadap US\$, populasi penduduk negara importir, dan kebijakan kuota ekspor) terhadap volume ekspor karet alam Indonesia ke Negara Jepang digunakan uji t-test. Berdasarkan hasil analisis uji t-test pada Tabel 3 menunjukkan bahwa variabel harga karet alam Indonesia di pasar internasional, volume ekspor karet alam Indonesia ke Negara Jepang satu tahun sebelumnya, harga riil karet alam di pasar internasional, harga riil karet alam dalam negeri, harga riil karet sintetis di pasar internasional, nilai tukar (exchange rate) Yen Jepang terhadap US\$, jumlah penduduk Negara Jepang, dan pendapatan per kapita Negara Jepang secara statistik berpengaruh atau signifikan terhadap volume ekspor karet alam Indonesia ke Negara Jepang.

Pada Tabel 3 volume ekspor karet alam Indonesia ke Negara Jepang satu tahun sebelumnya secara statistik menunjukkan pengaruh yang signifikan dan positif terhadap volume ekspor karet alam Indonesia ke Negara Jepang pada tingkat kepercayaan $95 \%$. Hal ini berarti bahwa apabila volume ekspor karet alam Indonesia ke Negara Jepang satu tahun sebelumnya meningkat 1\% dengan asumsi faktor lain dalam keadaan cateris paribus (tetap), maka volume ekspor karet alam Indonesia ke Negara Jepang mengalami peningkatan sebesar 0,5902\%. Oleh karena itu, volume ekspor karet alam Indonesia ke Negara Jepang satu tahun sebelumnya terdapat kecenderungan volume ekspor karet alam ke Negara Jepang tahun berikut mengalami peningkatan.

Harga riil karet alam di pasar internasional secara statistik berpengaruh nyata dan negatif terhadap volume ekspor karet alam Indonesia ke Negara Jepang pada tingkat kepercayaan 90\%. Besarnya nilai koefisien regresi dari variabel harga riil karet alam di pasar internasional 
adalah sebesar $-0,5387$. Hal ini menunjukkan bahwa apabila harga riil karet alam di pasar internasional meningkat $1 \%$ dengan asumsi faktor lain dalam keadaan tetap, maka volume ekspor karet alam Indonesia ke Negara Jepang mengalami penurunan sebesar nilai koefisien regresi dari variabel harga riil karet alam di pasar internasional $(0,5387 \%)$.

Harga riil karet alam di dalam negeri/domestik secara statistik berpengaruh nyata dan negatif terhadap volume ekspor karet alam Indonesia ke Negara Jepang pada tingkat kepercayaan 95\%. Besarnya nilai koefisien regresi dari variabel harga riil karet alam di dalam negeri/ domestik adalah sebesar $-0,2783$. Hal ini menunjukkan bahwa apabila harga riil karet alam di dalam negeri/ domestik meningkat $1 \%$ dengan asumsi faktor lain dalam keadaan tetap, maka volume ekspor karet alam Indonesia ke Negara Jepang mengalami penurunan sebesar nilai koefisien regresi dari variabel harga riil karet alam di dalam negeri/domestik $(0,2783 \%)$.

Selanjutnya, harga riil karet sintetis di pasar internasional secara statistik juga berpengaruh nyata dan positif terhadap volume ekspor karet alam Indonesia ke Negara Jepang pada tingkat kepercayaan 90\%. Besarnya nilai koefisien regresi dari variabel harga riil karet sintetis di pasar internasional adalah sebesar 0,2800. Hal ini menunjukkan bahwa, apabila harga riil karet sintetis di pasar internasional meningkat $1 \%$ dengan asumsi faktor lain dalam keadaan tetap, maka volume ekspor karet alam Indonesia ke Negara Jepang akan mengalami peningkatan sebesar nilai koefisien regresi dari variabel harga riil karet sintetis di pasar internasional $(0,2800 \%)$. Hal ini menunjukkan bahwa karet sintetis merupakan barang subtitusi dari karet alam.

Jumlah penduduk Negara Jepang secara statistik berpengaruh nyata terhadap volume ekspor karet alam Indonesia ke Negara Jepang pada tingkat kepercayaan $90 \%$. Besarnya nilai koefisien regresi dari variabel jumlah penduduk Negara Jepang adalah sebesar 3,6659. Hal ini menunjukkan bahwa apabila jumlah penduduk Negara Jepang meningkat $1 \%$ dengan asumsi faktor lain dalam keadaan tetap, maka volume ekspor karet alam Indonesia ke Negara Jepang mengalami peningkatan sebesar nilai koefisien regresi dari variabel jumlah penduduk Negara Jepang yakni sebesar 3,6659\%.

Variabel pendapatan per kapita Negara Jepang juga secara statistik berpengaruh nyata dan positif terhadap volume ekspor karet alam Indonesia ke Negara Jepang pada tingkat kepercayaan 99\%. Besarnya nilai koefisien regresi dari variabel pendapatan per kapita Negara Jepang adalah sebesar 0,8221. Hal ini menunjukkan bahwa apabila pendapatan per kapita Negara Jepang meningkat $1 \%$ dengan asumsi faktor lain dalam keadaan tetap, maka volume ekspor karet alam Indonesia ke Negara Jepang mengalami peningkatan sebesar nilai koefisien regresi dari variabel pendapatan per kapita Negara Jepang yakni sebesar 0,8221\%.

Kebijakan kuota ekspor secara statistik menunjukkan pengaruh yang signifikan terhadap volume ekspor karet alam Indonesia ke Negara Jepang. Hal ini menunjukkan bahwa terdapat perbedaan yang signifikan terhadap volume ekspor karet alam Indonesia dengan dikeluarkan kebijakan pembatasan kuota ekspor yakni adanya kebijakan kuota ekspor tersebut dapat menghambat atau menurunkan volume ekspor karet alam ke Negara Jepang. Besarnya nilai penurunan volume ekspor karet alam ke Negara Jepang dengan adanya kebijakan pembatasan kuota ekspor adalah sebesar 0,4145\%.

\section{TABEI 4. FAKTOR-FAKTOR YANG MEMPENGARUHI PERMINTAAN KARET ALAM INDONESIA KE NEGARA SINGAPURA}

\begin{tabular}{|c|c|c|c|}
\hline No & Nama Variabel & Koef. regresi & T-hitung \\
\hline 1 & $\begin{array}{l}\text { Volume ekspor tahun lalu ke } \\
\text { Singapura (Qdt_l) }\end{array}$ & $0,1500^{* *}$ & 2,165 \\
\hline 2 & $\begin{array}{l}\text { Harga riil karet alam di } \\
\text { pasar internasional (Pt) }\end{array}$ & $-0,5561^{*}$ & $-1,696$ \\
\hline 3 & $\begin{array}{l}\text { Harga riil karet alam dalam } \\
\text { negeri }(P d)\end{array}$ & $-0,1110^{* * *}$ & $-4,111$ \\
\hline 4 & Harga riil karet sintetis (PAt) & $0,5021^{*}$ & 1,758 \\
\hline 5 & $\begin{array}{l}\text { Pendapatan per kapita } \\
\text { Singapura (It) }\end{array}$ & $0,3280^{* *}$ & 2,158 \\
\hline 6 & $\begin{array}{l}\text { Nilai tukar dolar Singapura } \\
\text { terhadap US\$ (ERt) }\end{array}$ & $-0,1720^{* * *}$ & $-4,451$ \\
\hline 7 & $\begin{array}{l}\text { Populasi penduduk } \\
\text { Singapura (Popt) }\end{array}$ & $0,5821^{* *}$ & 2,250 \\
\hline 8 & $\begin{array}{l}\text { Kebijakan kuota ekspor } \\
\text { (Dummy) }\end{array}$ & $-0,1878^{\mathrm{NS}}$ & $-0,645$ \\
\hline \multirow[t]{3}{*}{9} & Constant & $0,8861^{* * *}$ & 2,988 \\
\hline & $R^{2}$ & 0,9628 & \\
\hline & $\begin{array}{l}\mathrm{F}_{\text {hit }} \\
\text { Durbin Watson Test (DW) }\end{array}$ & & $\begin{array}{l}119,647^{* * *} \\
1,9704\end{array}$ \\
\hline
\end{tabular}




\section{NEGARA SINGAPURA}

Hasil analisis faktor-faktor yang mempengaruhi Volume ekspor karet alam Indonesia ke Negara Singapura seperti ditunjukkan pada Tabel 4 .

Uji secara keseluruhan dari hasil analisis permintaan ekspor karet alam Indonesia ke Negara Singapura diperoleh nilai koefisien determinasi $\left(\mathrm{R}^{2}\right)$ sebesar 0,9122. Hal ini berarti sekitar 91,22\% variasi volume ekspor karet alam Indonesia ke Negara Singapura dapat dijelaskan oleh volume ekspor karet alam Indonesia ke negara importir tahun lalu, harga riil karet alam Indonesia di pasar internasional, harga riil karet alam dalam negeri/dmestik, harga riil karet sintetis negara importir, pendapatan per kapita negara importir, nilai tukar (exchange rate) dolar Singapura terhadap US\$, populasi penduduk negara importir, dan kebijakan kuota ekspor yang ada dalam model, sementara sisanya $(8,78 \%)$ variasi volume ekspor karet alam Indonesia ke Negara Singapura ditentukan oleh variabel bebas lain di luar model analisis yang digunakan.

Untuk melihat pengaruh secara keseluruhan variabel bebas (volume ekspor karet alam Indonesia ke negara importir tahun lalu, harga riil karet alam Indonesia di pasar internasional, harga riil karet alam dalam negeri/ dmestik, harga riil karet sintetis negara importir, pendapatan per kapita negara importir, nilai tukar (exchange rate) dolar Singapura terhadap US\$, populasi penduduk negara importir, dan kebijakan kuota ekspor) secara bersama-sama terhadap volume ekspor karet alam Indonesia ke Negara Singapura digunakan uji F-test. Bersasrkan hasil analisis pada Tabel 6.4 diperoleh nilai Fhitung sebesar 119,647 dan nilai ini jauh lebih besar dari nilai F-tabel pada tingkat kesalahan $1 \%(a ́=1 \%)$. Hal ini menunjukkan bahwa variabel bebas dalam model secara bersama-sama berpengaruh nyata terhadap volume ekspor karet alam Indonesia ke Negara Singapura pada tingkat kepercayaan 99\%.

Untuk melihat pengaruh masing-masing variabel bebas (volume ekspor karet alam Indonesia ke negara importir tahun lalu, harga riil karet alam Indonesia di pasar internasional, harga riil karet alam dalam negeri/ dmestik, harga riil karet sintetis negara importir, pendapatan per kapita negara importir, nilai tukar (exchange rate) dolar Singapura terhadap US\$, populasi penduduk negara importir, dan kebijakan kuota ekspor) terhadap volume ekspor karet alam Indonesia ke Negara Singapura digunakan uji t-test. Berdasarkan hasil analisis uji t-test pada Tabel 4 menunjukkan bahwa variabel harga karet alam Indonesia di pasar internasional, harga riil karet alam dalam negeri, volume ekspor karet alam Indonesia ke Negara Singapura satu tahun sebelumnya, harga riil karet sintetis di pasar internasional, nilai tukar dolar Singapura terhadap US\$, jumlah penduduk Negara Singapura, dan pendapatan per kapita Negara Singapura secara statistik berpengaruh atau signifikan terhadap volume ekspor karet alam Indonesia ke Negara Singapura.

Pada Tabel 4 volume ekspor karet alam Indonesia ke Negara Singapura satu tahun sebelumnya secara statistik menunjukkan pengaruh yang signifikan dan positif terhadap volume ekspor karet alam Indonesia ke Negara Singapura pada tingkat kepercayaan 99\%. Hal ini berarti bahwa apabila volume ekspor karet alam Indonesia ke Negara Singapura satu tahun sebelumnya meningkat 1\% dengan asumsi faktor lain dalam keadaan cateris paribus (tetap), maka volume ekspor karet alam Indonesia ke Negara Singapura mengalami peningkatan sebesar 0,1500\%. Oleh karena itu, volume ekspor karet alam Indonesia ke Negara Singapura satu tahun sebelumnya terdapat kecenderungan volume ekspor karet alam ke Negara Singapura tahun berikut mengalami peningkatan.

Harga riil karet alam di pasar internasional secara statistik berpengaruh nyata terhadap volume ekspor karet alam Indonesia ke Negara Singapura pada tingkat kepercayaan 90\%. Besarnya nilai koefisien regresi dari variabel harga riil karet alam di pasar internasional adalah sebesar -0,5561. Hal ini menunjukkan bahwa apabila harga riil karet alam di pasar internasional meningkat 1\% dengan asumsi faktor lain dalam keadaan tetap, maka volume ekspor karet alam Indonesia ke Negara Singapura mengalami penurunan sebesar nilai koefisien regresi dari variabel harga riil karet alam di pasar internasional $(0,5561 \%)$.

Harga riil karet alam dalam negeri secara statistik berpengaruh nyata terhadap volume ekspor karet alam Indonesia ke Negara Singapura pada tingkat kepercayaan 99\%. Besarnya nilai koefisien regresi dari variabel harga riil karet alam dalam negeri adalah sebesar -0,1110. Hal ini menunjukkan bahwa apabila harga riil karet alam dalam negeri meningkat 1\% dengan asumsi faktor lain dalam keadaan tetap, maka volume ekspor karet alam Indonesia ke Negara Singapura mengalami penurunan sebesar nilai koefisien regresi dari variabel harga riil karet alam dalam negeri yakni sebesar 0,1110\%.

Selanjutnya, harga riil karet sintetis di pasar 
internasional secara statistik juga berpengaruh nyata dan positif terhadap volume ekspor karet alam Indonesia ke Negara Singapura pada tingkat kepercayaan 90\%. Besarnya nilai koefisien regresi dari variabel harga riil karet sintetis di pasar internasional adalah sebesar 0,5021. Hal ini menunjukkan bahwa, apabila harga riil karet sintetis di pasar internasional meningkat $1 \%$ dengan asumsi faktor lain dalam keadaan tetap, maka volume ekspor karet alam Indonesia ke Negara Singapura akan mengalami peningkatan sebesar nilai koefisien regresi dari variabel harga riil karet sintetis di pasar internasional $(0,5021 \%)$. Hal ini menunjukkan bahwa karet sintetis merupakan barang subtitusi dari karet alam.

Selanjutnya, nilai tukar (exchange rate) dolar Singapura terhadap US\$ secara statistik juga berpengaruh nyata dan negatif terhadap volume ekspor karet alam Indonesia ke Negara Singapura pada tingkat kepercayaan 99\%.

Besarnya nilai koefisien regresi dari variabel nilai tukar (exchange rate) dolar Singapura terhadap US\$ adalah sebesar -0,1720. Hal ini menunjukkan bahwa, apabila nilai tukar (exchange rate) dolar Singapura terhadap US\$ meningkat $1 \%$ dengan asumsi faktor lain dalam keadaan tetap, maka volume ekspor karet alam Indonesia ke Negara Singapura akan mengalami penurunan sebesar nilai koefisien regresi dari variabel nilai tukar (exchange rate) dolar Singapura terhadap US\$ yakni sebesar $0,1720 \%$.

Variabel jumlah penduduk Negara Singapura juga secara statistik berpengaruh nyata dan positif terhadap volume ekspor karet alam Indonesia ke Negara Singapura pada tingkat kepercayaan 95\%. Besarnya nilai koefisien regresi dari variabel jumlah penduduk Negara Singapura adalah sebesar 0,5821. Hal ini menunjukkan bahwa apabila jumlah penduduk Negara Singapura meningkat 1\% dengan asumsi faktor lain dalam keadaan tetap, maka volume ekspor karet alam Indonesia ke Negara Singapura mengalami peningkatan sebesar nilai koefisien regresi dari variabel jumlah penduduk Negara Singapura yakni sebesar 0,5851\%.

Variabel pendapatan per kapita Negara Singapura juga secara statistik berpengaruh nyata dan positif terhadap volume ekspor karet alam Indonesia ke Negara Singapura pada tingkat kepercayaan 95\%. Besarnya nilai koefisien regresi dari variabel pendapatan per kapita Negara Singapura adalah sebesar 0,3280. Hal ini menunjukkan bahwa apabila pendapatan per kapita Negara Singapura meningkat 1\% dengan asumsi faktor lain dalam keadaan tetap, maka volume ekspor karet alam Indonesia ke
Negara Singapura mengalami peningkatan sebesar nilai koefisien regresi dari variabel pendapatan per kapita Negara Singapura yakni sebesar 0,3280\%.

\section{NEGARA KOREA SELATAN}

Hasil analisis faktor-faktor yang mempengaruhi Volume ekspor karet alam Indonesia ke Negara Korea Selatan seperti ditunjukkan pada Tabel 5 .

\section{TABEI 5. FAKTOR-FAKTOR YANG MEMPENGARUHI PERMINTAAN KARET ALAM INDONESIA KE NEGARA KOREA SELATAN}

\begin{tabular}{|c|c|c|c|}
\hline No & Nama Variabel & Koef. regresi & T-hitung \\
\hline 1 & $\begin{array}{l}\text { Volume ekspor tahun lalu ke } \\
\text { Korea Selatan (Qdt_l) }\end{array}$ & $0,3646^{* * *}$ & 3,676 \\
\hline 2 & $\begin{array}{l}\text { Harga riil karet alam di } \\
\text { pasar internasional (Pt) }\end{array}$ & $-0,5473^{* * *}$ & $-3,447$ \\
\hline 3 & $\begin{array}{l}\text { Harga riil karet alam dalam } \\
\text { negeri }(\mathrm{Pd})\end{array}$ & $0,1486^{\mathrm{NS}}$ & 0,378 \\
\hline 4 & Harga riil karet sintetis (PAt) & $-0,0988^{\text {NS }}$ & $-0,291$ \\
\hline 5 & $\begin{array}{l}\text { Pendapatan per kapita } \\
\text { Korea Selatan (It) }\end{array}$ & $1,3177^{*}$ & 1,996 \\
\hline 6 & $\begin{array}{l}\text { Nilai tukar Yuan terhadap } \\
\text { USS (ERt) }\end{array}$ & $-0,2191^{*}$ & $-1,956$ \\
\hline 7 & $\begin{array}{l}\text { Jumlah penduduk Korea } \\
\text { Selatan (Popt) }\end{array}$ & $0,2956^{* * *}$ & 2,768 \\
\hline 8 & $\begin{array}{l}\text { Kebijakan kuota ekspor } \\
\text { (Dummy) }\end{array}$ & $-0,5890^{* * *}$ & $-2,552$ \\
\hline 9 & Constant & $9,1947^{\mathrm{NS}}$ & 0,444 \\
\hline & $R^{2}$ & 0,9122 & \\
\hline & $\begin{array}{l}F_{\text {hit }} \\
\text { Durbin Watson Test (DW) }\end{array}$ & & $\begin{array}{l}32,453^{* * *} \\
1,9630\end{array}$ \\
\hline
\end{tabular}

Keterangan: $\left.{ }^{* * *}\right)$ signifikan pada á $=1 \%$; ${ }^{* *}$ ) signifikan pada á $=5 \%$; *) siginifikan pada á $=10 \%$; ${ }^{\text {Ns }}=$ tidak signifikan

Uji secara keseluruhan dari hasil analisis permintaan ekspor karet alam Indonesia ke Negara Korea Selatan diperoleh nilai koefisien determinasi $\left(\mathrm{R}^{2}\right)$ sebesar 0,9122. Hal ini berarti sekitar 91,22\% variasi volume ekspor karet alam Indonesia ke Negara Korea Selatan dapat dijelaskan oleh volume ekspor karet alam Indonesia ke negara importir tahun lalu, harga riil karet alam Indonesia di pasar internasional, harga riil karet alam dalam negeri/dmestik, harga riil karet sintetis negara importir, pendapatan per kapita negara importir, nilai tukar (exchange rate) mata uang Korea Selatan terhadap US\$, populasi penduduk negara importir, dan kebijakan kuota 
ekspor yang ada dalam model, sementara sisanya $(8,78 \%)$ variasi volume ekspor karet alam Indonesia ke Negara Korea Selatan ditentukan oleh variabel bebas lain di luar model analisis yang digunakan.

Untuk melihat pengaruh secara keseluruhan variabel bebas (volume ekspor karet alam Indonesia ke negara importir tahun lalu, harga riil karet alam Indonesia di pasar internasional, harga riil karet alam dalam negeri/ dmestik, harga riil karet sintetis negara importir, pendapatan per kapita negara importir, nilai tukar (exchange rate) mata uang Korea Selatan terhadap US\$, populasi penduduk negara importir, dan kebijakan kuota ekspor) secara bersama-sama terhadap volume ekspor karet alam Indonesia ke Negara Korea Selatan digunakan uji F-test. Bersasrkan hasil analisis pada Tabel 5 diperoleh nilai F-hitung sebesar 31,960 dan nilai ini jauh lebih besar dari nilai F-tabel pada tingkat kesalahan 1\% (á = 1\%). Hal ini menunjukkan bahwa variabel bebas dalam model secara bersama-sama berpengaruh nyata terhadap volume ekspor karet alam Indonesia ke Negara Korea Selatan pada tingkat kepercayaan 99\%.

Untuk melihat pengaruh masing-masing variabel bebas (volume ekspor karet alam Indonesia ke negara importir tahun lalu, harga riil karet alam Indonesia di pasar internasional, harga riil karet alam dalam negeri/ dmestik, harga riil karet sintetis negara importir, pendapatan per kapita negara importir, nilai tukar (exchange rate) mata uang Korea Selatan terhadap US\$, populasi penduduk negara importir, dan kebijakan kuota ekspor) terhadap volume ekspor karet alam Indonesia ke Negara Korea Selatan digunakan uji t-test. Berdasarkan hasil analisis uji t-test pada Tabel 5 menunjukkan bahwa variabel harga karet alam Indonesia di pasar internasional, volume ekspor karet alam Indonesia ke Negara Korea Selatan satu tahun sebelumnya, harga riil karet alam di pasar internasional, nilai tukar (exchange rate) mata uang Korea Selatan terhadap US\$, jumlah penduduk Korea Selatan, dan pendapatan per kapita Korea Selatan secara statistik berpengaruh atau signifikan terhadap volume ekspor karet alam Indonesia ke Negara Korea Selatan.

Pada Tabel 5 volume ekspor karet alam Indonesia ke Negara Korea Selatan satu tahun sebelumnya secara statistik menunjukkan pengaruh yang signifikan dan positif terhadap volume ekspor karet alam Indonesia ke Negara Korea Selatan pada tingkat kepercayaan 99\%. Hal ini berarti bahwa apabila volume ekspor karet alam Indonesia ke Negara Korea Selatan satu tahun sebelumnya meningkat $1 \%$ dengan asumsi faktor lain dalam keadaan cateris paribus (tetap), maka volume ekspor karet alam Indonesia ke Negara Korea Selatan mengalami peningkatan sebesar 0,3646\%. Oleh karena itu, volume ekspor karet alam Indonesia ke Negara Korea Selatan satu tahun sebelumnya terdapat kecenderungan volume ekspor karet alam ke Negara Korea Selatan tahun berikut mengalami peningkatan.

Harga riil karet alam di pasar internasional secara statistik berpengaruh nyata terhadap volume ekspor karet alam Indonesia ke Negara Korea Selatan pada tingkat kepercayaan 99\%. Besarnya nilai koefisien regresi dari variabel harga riil karet alam di pasar internasional adalah sebesar -0,5472. Hal ini menunjukkan bahwa apabila harga riil karet alam di pasar internasional meningkat $1 \%$ dengan asumsi faktor lain dalam keadaan tetap, maka volume ekspor karet alam Indonesia ke Negara Korea Selatan mengalami penurunan sebesar nilai koefisien regresi dari variabel harga riil karet alam di pasar internasional $(0,5472 \%)$.

Selanjutnya, nilai tukar (exchange rate) mata uang Korea Selatan terhadap US\$ secara statistik juga berpengaruh nyata dan negatif terhadap volume ekspor karet alam Indonesia ke Negara Korea Selatan pada tingkat kepercayaan 90\%. Besarnya nilai koefisien regresi dari variabel nilai tukar (exchange rate) mata uang Korea Selatan terhadap US \$ adalah sebesar 0,2191. Hal ini menunjukkan bahwa, apabila nilai tukar (exchange rate) mata uang Korea Selatan terhadap US\$ meningkat 1\% dengan asumsi faktor lain dalam keadaan tetap, maka volume ekspor karet alam Indonesia ke Negara Korea Selatan akan mengalami peningkatan sebesar nilai koefisien regresi dari variabel nilai tukar (exchange rate) mata uang Korea Selatan terhadap US\$ (0,2191\%).

Jumlah penduduk Negara Korea Selatan secara statistik berpengaruh nyata terhadap volume ekspor karet alam Indonesia ke Negara Korea Selatan pada tingkat kepercayaan 99\%. Besarnya nilai koefisien regresi dari variabel jumlah penduduk Negara Korea Selatan adalah sebesar 0,2956. Hal ini menunjukkan bahwa apabila jumlah penduduk Negara Korea Selatan meningkat 1\% dengan asumsi faktor lain dalam keadaan tetap, maka volume ekspor karet alam Indonesia ke Negara Korea Selatan mengalami peningkatan sebesar nilai koefisien regresi dari variabel jumlah penduduk Negara Korea Selatan yakni sebesar 0,2956\%.

Variabel pendapatan per kapita Negara Korea Selatan juga secara statistik berpengaruh nyata dan positif 
terhadap volume ekspor karet alam Indonesia ke Negara Korea Selatan pada tingkat kepercayaan 90\%. Besarnya nilai koefisien regresi dari variabel pendapatan per kapita Negara Korea Selatan adalah sebesar 1,3177. Hal ini menunjukkan bahwa apabila pendapatan per kapita Negara Korea Selatan meningkat 1\% dengan asumsi faktor lain dalam keadaan tetap, maka volume ekspor karet alam Indonesia ke Negara Korea Selatan mengalami peningkatan sebesar nilai koefisien regresi dari variabel pendapatan per kapita Negara Korea Selatan yakni sebesar 1,3177\%.

Kebijakan kuota ekspor secara statistik menunjukkan pengaruh yang signifikan terhadap volume ekspor karet alam Indonesia ke Negara Korea Selatan. Hal ini menunjukkan bahwa terdapat perbedaan yang signifikan terhadap volume ekspor karet alam Indonesia dengan dikeluarkan kebijakan pembatasan kuota ekspor yakni adanya kebijakan kuota ekspor tersebut dapat menghambat atau menurunkan volume ekspor karet alam ke Negara Korea Selatan. Besarnya nilai penurunan volume ekspor karet alam ke Negara Korea Selatan dengan adanya kebijakan pembatasan kuota ekspor adalah sebesar 0,5770\%.

Variabel bebas lain yang masuk dalam model analisis yaitu harga riil karet alam dalam negeri dan harga riil karet sintetis dipasar internasional secara statistik tidak menunjukkan pengaruh yang nyata (non signifikan) terhadap volume ekspor karet alam Indonesia ke Negara Korea Selatan. Hal ini menunjukkan bahwa terjadinya perubahan pada nilai dari variabel harga riil karet alam dalam negeri dan harga riil karet sintetis dipasar internasional secara statistik tidak berpengaruh terhadap volume ekspor karet alam Indonesia ke Negara Korea Selatan.

\section{KESIMPULAN}

1. Permintaan volume ekspor karet alam Indonesia ke negara:

a. Amerika Serikat dipengaruhi secara positif oleh volume ekspor tahun lalu ke Amerika Serikat, pendapatan per Amerika Serikat, dan jumlah penduduk Amerika Serikat serta dipengaruhi secara negatif oleh harga riil karet alam dipasar internasional, dan pemberlakuan kebijakan kuota ekspor.

b. China dipengaruhi secara positif oleh volume ekspor tahun lalu ke Negara China, pendapatan per Negara China, dan jumlah penduduk Negara China serta dipengaruhi secara negatif oleh harga riil karet alam dalam negeri, Nilai tukar Yuan terhadap US\$, dan pemberlakuan kebijakan kuota ekspor.

c. Jepang dipengaruhi secara positif oleh volume ekspor tahun lalu ke Negara Jepang, pendapatan per Negara Jepang, harga riil karet sintetis di pasar internasional, dan jumlah penduduk Negara Jepang serta dipengaruhi secara negatif oleh harga riil karet alam di pasar internasional dan pemberlakuan kebijakan kuota ekspor.

d. Singapura dipengaruhi secara positif oleh volume ekspor tahun lalu ke Negara Singapura, dan jumlah penduduk Negara Singapura serta dipengaruhi secara negatif oleh harga riil karet alam di pasar internasional dan pemberlakuan kebijakan kuota ekspor.

e. Korea Selatan dipengaruhi secara positif oleh volume ekspor tahun lalu ke Negara Korea Selatan, pendapatan per kapita Negara Korea Selatan dan jumlah penduduk Negara Korea Selatan serta dipengaruhi secara negatif oleh harga riil karet alam di pasar internasional, nilai tukar mata uang Korea Selatan terhadap US\$ dan pemberlakuan kebijakan kuota ekspor.

\section{SARAN}

Untuk meningkatkan volume ekspor karet alam Indonesia dengan memanfaatkan momentum peningkatan permintaan karet alam dunia yang terus meningkat utamanya pada lima Negara tujuan ekspor yakni Negara Amerika Serikat, Negara China, Negara Jepang, Negara Singapura, dan Negara Korea Selatan perlu memperhatikan faktor-faktor yang berpengaruh baik secara positif maupun secara negatif pada masingmasing Negara.

\section{DAFTAR PUSTAKA}

Anonim, 2006. Kerjasama "Tripartite" Komoditas Karet (ITRC) di Bali. Direktorat Budidaya Tanaman Tahunan. Departemen Pertanian, Jakarta.

Badan Penelitian dan Pengembangan Pertanian, 2007. 
Prospek dan Arah Pengembangan Agribisnis Karet Ed.2.

Balitbang Pertanian. Departemen Pertanian. Jakarta.

Boediono, 1981. Ekonomi Internasional, Pengantar Ilmu Ekonomi, Seri Sinopsis.Edisi Pertama. BPFE, Yogyakarta.

Darwanto, D.H., 2004. Agribisnis Internasional. MMA

UGM, Yogyakarta.

Fao, 2014. Food and Agriculture Organization. website

http://www.faostat.fao.org/site/342/default.aspx. diakses Mei 2014

Gapkindo, 2014. Gabungan Pengusaha Karet Indonesia.

Website http://www.gapkindo.co.id (diakses maret 2014).

Gujarati Damodar, 2003. Econometrics. Mc-Graw Hill,

INC, New York.

Hapsari, Ella. 2008. Analisis Permintaan Ekspor Karet

Alam Indonesia di Negara Cina. Skripsi. Program Studi

Ekonomi Pertanian dan Sumberdaya. Fakultas

Pertanian : IPB.

Harry H., 2003. Ekonomi Internasional. Rineka Cipta, Jakarta.

Hendra H., 2005. Ekonomi Internasional dan Globalisasi Ekonomi, Edisi Kedua. Ghalia Indonesia.

Ilyas, Ramlan. 1991. Analisis Permintaan Luar Negeri

Terhadap Kopi Indonesia. Tesis. Pasca Sarjana Program Studi Ekonomi Pertanian, Fakultas Pertanian : UGM.

Kindleberger, C.P and Peter H. Lindert, 1991. International Economic. Ninth Edition. Richard D. Irwin, California.

Koutsoyiannis A. 1983. Modern Microeconomics. Second Edition. English Laguage Booksociety, Mac.Millan.

Krugman Paul R. dan Maurice Obstfeld. 2002. Ekonomi Internasional: Teori dan Kebijakan. Edisi Kedua. PT Raja Grafindo Persada. Jakarta.

Lipsey, Richard G and Peter O.S, 1981. Economics, Sixth Edition. Harper and Row Publisher, New York.

Lindert P.H, 1991. International Economics. Ninth Edition. Richard D. Irwin. California.

Nerlove M, 1958. Distributed Lags and Estimation of Long Run Supply and Demand Elasticities Theoritical Consideration. Journal of Farm Economics, XL(2):301-311.

Nopirin, 1995. Ekonomi Internasional, Edisi Ketiga. BPFE, Yogyakarta.

Payaman J. Simanjuntak, 1983. Masalah Tenaga Kerja di Subsektor Perkebunan. Dalam Buku Perkebunan Indonesia di Masa Depan. Yayasan Agro Ekonomika, Jakarta.
Pindyck, Robert S and Daniel L. Rubinfield, 1991. Econometric Models and Economic Forecast. M.Graw-Hill, USA.

Rubandiah,. 2008. Analisis Permintaan Ekspor Kakao Indonesia. Tesis. Pasca Sarjana Program Studi Ekonomi Pertanian, Fakultas Pertanian : UGM.

Silalahi, Agnes Verawaty. 2008. Faktor-faktor yang Mempengaruhi Ekspor Karet Indonesia. Tesis. Magister Manajemen Agribisnis : UGM.

Shinta A, Masyhuri, dan Soedjono A., 1997. Analisis

Penawaran dan Permintaan Ekspor Karet Alam Indonesia, BPPS-UGM.

Salvatore, D. 1997. Ekonomi Internsional (Terjemahan). Erlangga. Jakarta.

Soediyono, 1984. Ekonomi Internasional, Pengantar Lalu Lintas Pembayaran Internasional. Liberty, Yogyakarta. Spillane, J., 1989. Komoditas Karet Peranannya dalam Perekonomian Indonesia. Penerbit Kanisius, Yogyakarta. Suharto,.1989. Analisis Permintaan dan Ekspor Teh Indonesia. Tesis. Pasca Sarjana Program Studi Ekonomi Pertanian, Fakultas Pertanian : UGM.

Tim Penulis PS, 1992. Karet Strategi Pemasaran, Budidaya dan Pengolahan. Penerbit Swadaya, Jakarta.

Timmer, C.P, 1984. Com Marketing and The Balance Between Domestic Production and Consumption. Working Paper No.14. Bulog-Stanford Com Project, November:quoted in Heytem.

Tambunan T, 2000. Perdagangan Internasional dan Neraca Pembayaran, Teori dan Temuan Empiris. LP3ES, Jakarta.

Tambunan, T.T.H., 2004. Globalisasi dan Perdagangan Internasional. Ghalia Indonesia. Bogor.

Widayati, S. 2008. Neraca Perdagangan Komoditi Karet Antara Indonesia dengan Amerika Serikat. Jurnal Pertanian Mapeta Vol.10 No.3 Agustus 2008 : 154 163. Jurusan MMA, Fakultas Pertanian UPN. Jawa Timur.

Widodo S, 2007. Hand Out Ekonomi Mikro. Fakultas Pertanian UGM, Yogyakarta.

Wilantari, R. 2001. Analisis Permintaan Ekspor Karet Alam Indonesia dari Jepang dan Amerika Serikat (1969 - 1998). Tesis. Pasca Sarjana Program Studi Ekonomika dan Bisnis. Fakultas ekonomi : UGM. Wiranatha M., 2006. Metodologi Penelitian Sosial. Penerbit Andi Offset, Yogyakarta. 